\title{
EFFECT OF VIBRATION SHOT PEENING PARAMETERS UPON SHAPES OF BEARING CURVES OF ALLOY STEEL SURFACE
}

\author{
Kazimierz Zaleski ${ }^{1}$, Agnieszka Skoczylas ${ }^{1}$ \\ 1 Lublin University of Technology, 36 Nadbystrzycka Str., 20-618 Lublin, Poland, e-mail: k.zaleski@pollub.pl; \\ a.skoczylas@pollub.pl
}

Received: 2015.01 .30

Accepted: 2015.02.14

Published: 2015.03.01

\begin{abstract}
The article presents the results of studies on the effect of technological parameters of vibration shot peening upon the shape of bearing curves and the parameters of that curve. The topography of surface formed in result of vibration shot peening and pre-machining, which was grinding, were analyzed. The material used in the studies was alloy steel 30 HGSA. The shot peening process was performed on an appliance equipped with a kinematic vibrator. Shot peening time $t$, vibrator oscillations (vibrations) frequency $v$, as well as vibrator oscillations amplitude $A$ were changed within: $t=1-15 \mathrm{~min}, v=17,5-35 \mathrm{~Hz}, A=10,3-17,3 \mathrm{~mm}$. For measuring surface roughness and determining the bearing curve the appliance T8000 RC120-400 by HommelEtamic was used together with the software. In result of the machining performed surface roughness decreased, and the parameters of bearing curve improved.
\end{abstract}

Keywords: vibration shot peening, bearing curve, surface roughness.

\section{INTRODUCTION}

Vibration shot peening is one of the variants of dynamic burnishing, characterized by striking effect of shot peening elements, most often in a form of balls, upon the treated object. The formation of the surface of geometrical structure during shot peening is a complex structure, including "knocking out" hollows, leveling micro-elevations formed in earlier phases of shot peening and accruing hardening of the surface layer in result of condensation traces of blows [12].

Roughness of treated objects surfaces can be characterized by means of numerous parameters [16]. The most frequently applied roughness parameters $(\mathrm{Ra}, \mathrm{Rz})$ do not allow for a full assessment of operating properties of treated surfaces. Important information about tribological properties of a given surface is provided by bearing curve, also called the Abbott-Firestone curve $[1,11,15]$.

The (mating) surfaces of a tribological pair should be divided by a layer of a smearing liquid.
The hydrodynamic (buoyant force) of that liquid depends upon the geometrical structure of the (mating) surfaces [3]. The bearing curve of the surface whose shape depends upon the method of machining that surface, affects the thickness of the smearing film [10].

A number of authors present the results of studying various treatments of machining methods affecting the shape of bearing curve of the machined surface. The effect of the technological parameters of turning treatment upon the shape of Abbott-Firestone curve was presented in the paper [9], and the influence of the kind of abradant upon the shape of that curve of the ground surface was shown in this paper as well as in [8]. One of the methods of finishing treatment, providing for obtaining the surface with high load capacity is honing. That is why in many works the effect of honing upon the indices of Abbott-Firestone curve is analyzed $[2,4,14]$.

Studies of the effect of burnishing upon load capacity of the machined surface. In this 
paper [7] the results of comparative studies of indices of the load capacity share of nodular cast iron after grinding and after roller burnishing. Shot peening allows forming hollows on the surfaces working in the conditions of seizing, which are grease pockets. It was found that the application of grease pockets influences the decrease of the wear of frictionally mating elements, as well as the increase of friction travel to seizing friction pair $[5,6]$.

Previous studies of surface quality after vibration shot peening comprised the effect of vibration shot peening parameters upon surface roughness, expressed by the parameter $R a$ [13]. The objective of the currently presented studies was to determine the effect of vibration shot peening parameters upon the shape bearing curve of the machined surface.

\section{RESEARCH METHODOLOGY}

In the experimental studies we used rectangular prism samples of dimensions: $4 \times 15 \times 100 \mathrm{~mm}$, made of alloy steel 30HGSA. After initial, forming treatment the samples underwent toughening to the hardness of 36-38 HRC, and then they were ground with the application of small feed and intense cooling.

The vibration burnishing was performed on a special appliance, equipped with a kinematic vibrator (Figure 1), giving the possibility of changing the vibration amplitude and frequency. The appliance consists of the working chamber (4), situated on the upper plate of the vibrator (1). Samples (2) are attached to the bottom of the chamber. These are covered by loose balls

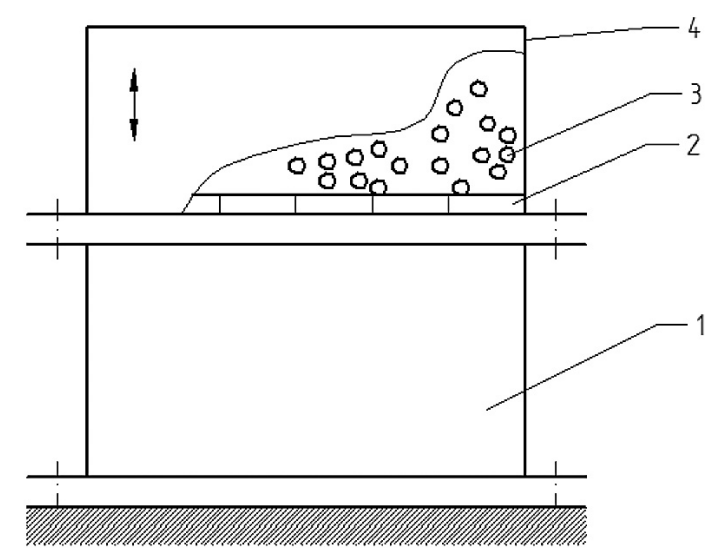

Fig. 1. Schema of a stand for vibration shot peening: 1 - vibrator, 2 - specimens, 3 - peening ball, 4 - chamber
(3), which, as a result of vibrations caused by the vibrator, collide with the treated surface, causing the effect of shot peening.

Vibration shot peening was accomplished for the following technological parameters: vibrator's vibration amplitude $A=(10.3-17.3)$ $\mathrm{mm}$, frequency of the vibrator's vibrations $v=(17.5-35) \mathrm{Hz}$ and shot peening time $t=(1-$ 15) min. The diameter of shot penning balls was $9.4 \mathrm{~mm}$. We know from the previous studies [13] that these parameters significantly affect the state of surface layer.

Measurements of surface roughness, topography and bearing curve parameters were performed with the use of Hommel-Etamic T8000 RC120-400 appliance and the software which is compatible with the equipment.

As the parameters of Abbott-Firestone curve the following were determined: $R k-$ depth of roughness body, that is a part of the profile, excluding the distinguishable elevations and deep hollows, $R p k$ - reduced height of elevations, $R v k$ - reduced depth of the hollow and the material ratio at depth $c$ roughness profile, $R m r$ on the level of reference $c=$ $1 \mu \mathrm{m}[15,16]$. In order to determine the material share of roughness profile the zero level was assumed and on the level of 5\% below the level containing extreme elevations, for which the reference level was determined. The current practice is to determine the bearing length coefficient in this way [11]. This allows for eliminating the effect of extreme elevations upon the result of measuring the relative material ratio at depth $\mathrm{c}$ roughness profile. Figure 2 shows the graphic interpretation of bearing curve for the roughness profile.

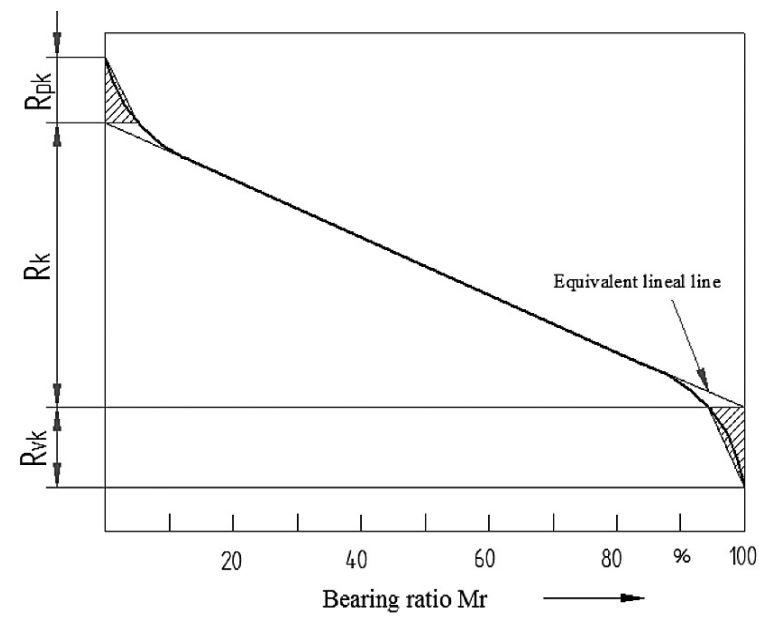

Fig. 2. Parameters bearing curve (based on [15]) 


\section{STUDY RESULTS}

The accomplishment of these studies allowed for presenting the effect of vibration shot peening parameters upon the parameters of bearing curve for roughness profile and upon the shape of Abbott-Firestone curve.

Figure 3 shows the bearing curve and topography for the surface after grinding. The surface after grinding is characterized by a unidirectional arrangement of micro-irregularities in uniform (equal) spacing. Deep scratches and sharp elevations are visible. The geometrical structure formed after grinding should be qualified as unidirectional. The Abbott-Firestone curve is a curve with a large angle of inclination, representing a surface with sharp vertexes. The profile of such a surface with small bearing is called a curve with a "thin center" [11].

The study results demonstrate that the technological parameters of vibration shot peening

a)

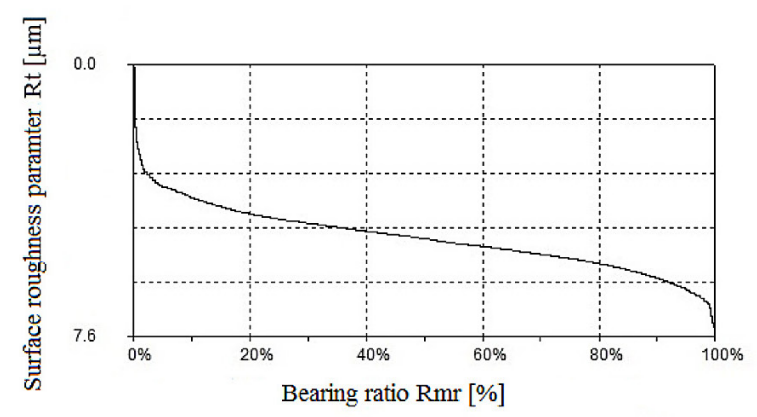

$\mathrm{Rt}=5.28 \mu \mathrm{m}( \pm 0.5868) ; \mathrm{Rk}=2.03 \mu \mathrm{m}( \pm 0.1881)$

$\mathrm{Rpk}=0.79 \mu \mathrm{m}( \pm 0.0774) ; \mathrm{Rvk}=1.02 \mu \mathrm{m}( \pm 0.1303)$ affect surface roughness and the parameters of Abbott-Firestone curve.

The graph presented in figure 4 shows that the change of shot peening time affects the parameters of bearing curve. Increasing burnishing time within the range from 1 to 5 minutes causes the decrease of surface roughness and the parameters: $R k, R v k, R p k$, what can be justified by the growing number of strikes falling on a surface unit. When the time is longer, a slight increase of bearing curve parameters takes place with reference to the minimal values achieved for $t=5 \mathrm{~min}$.

In the aspect of the two surfaces mating with each other, an important parameter is the material ratio at depth $c R m r$, determined in the accomplished studies on the reference level $c=1 \mu \mathrm{m}$. According to the supposition, the increase of burnishing time causes the increase of Rmr value (Figure 5). It should be explained by the increased number of strike traces on the machined surface, which contributes to achieving a less rough surface.

b)

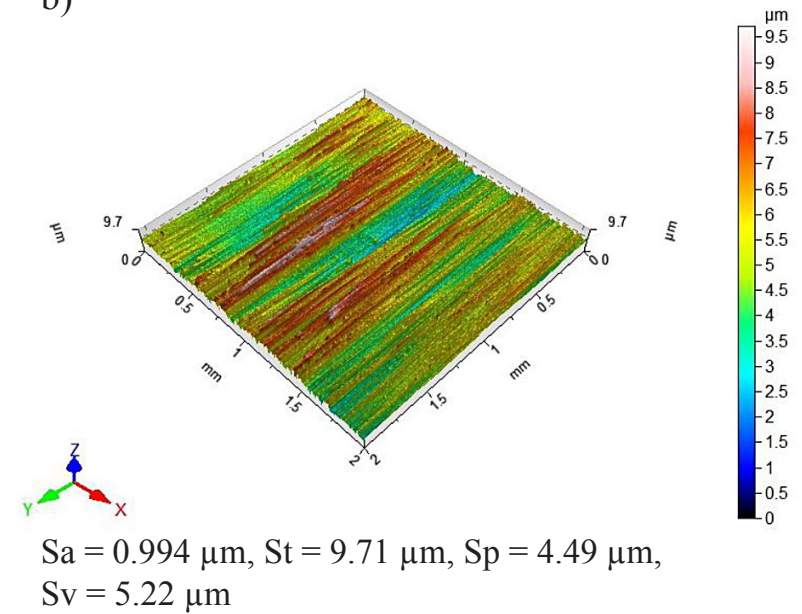

Fig. 3. Bearing curve, surface topography and surface roughness parameters $2 \mathrm{D}$ and $3 \mathrm{D}$ after grinding

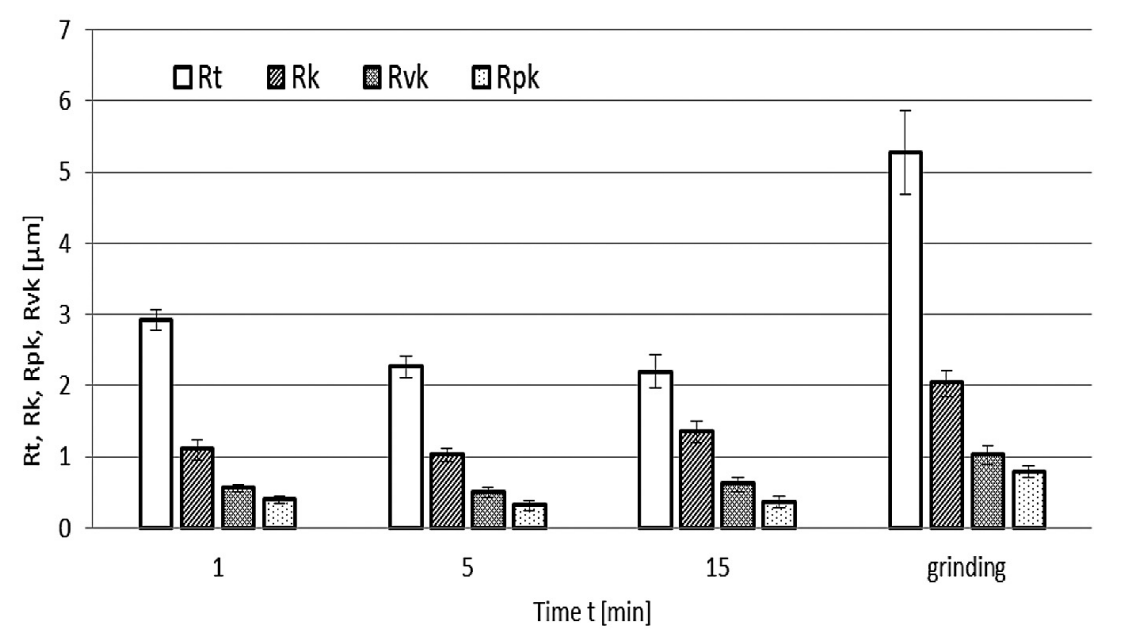

Fig. 4. Effect of vibration shot peening time onto surface roughness parameter and bearing ratio curve parameters 


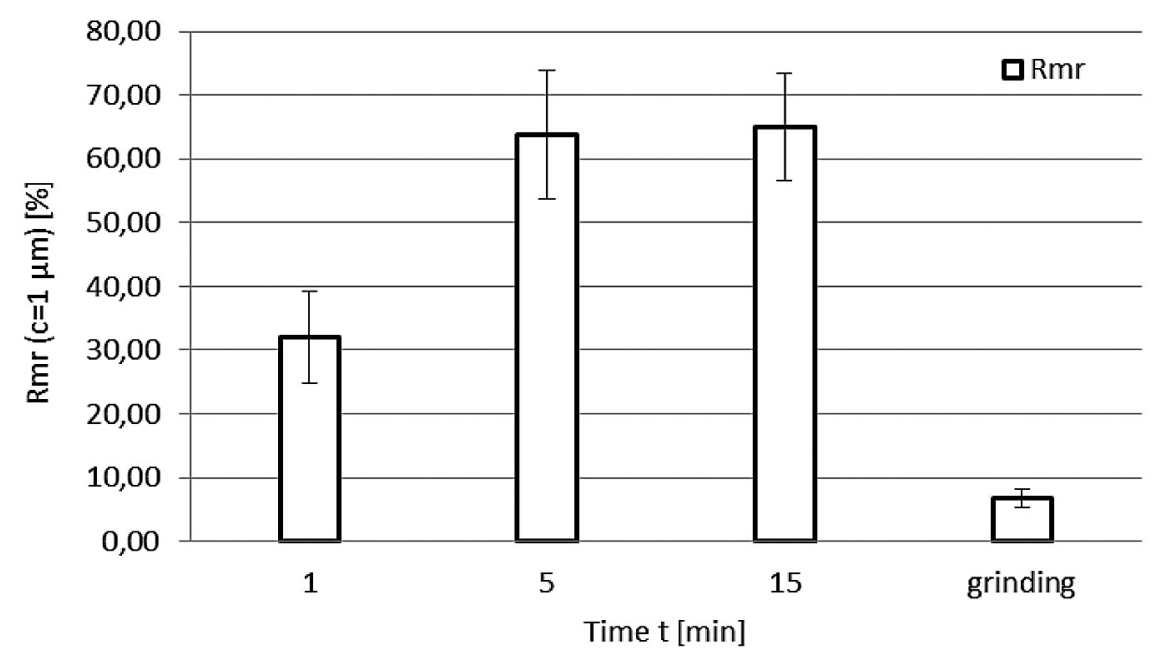

Fig. 5. Effect of vibration shot peening time onto material ratio at depth $c$ Rmr

Figure 6 presents the effect of vibrator vibrations frequency upon surface roughness and the parameters: $R k, R v k, R p k$. The increase of vibrator vibrations frequency is accompanied by increased impact energy and the number of impact falling on a surface unit, which is translated into higher values of material ratio at depth $c$ in the roughness profile. The most advantageous machining effects were achieved for the frequency $v=23.5 \mathrm{~Hz}$. For the frequency $v=$ $17.5 \mathrm{~Hz}$ the energy of impact does not achieve large values, which causes a smaller change in the surface roughness level Rt. In the case when $v=35 \mathrm{~Hz}$ "knocking out" of larger hollows in the machined surface takes place, which affects surface roughness and the parameters of AbbottFirestone curve. The effect of vibrator vibrations frequency upon the material ratio at depth $c$ is shown in Figure 7. At the beginning there is a visible increase of Rmr parameter, which later decreases for the maximal frequency.
Considering the effect of vibrator vibrations amplitude upon the parameters of bearing curve (Figures 8 and 9) an increase of the examined parameters can be noticed, together with the increased amplitude. That is connected with the increased energy of balls colliding with the shot peened samples, the consequence of which is increased surface roughness. That may lead to a deteriorating resistance of that surface to abrasive wear (attrition). The optimal conditions, allowing for obtaining advantageous conditions of bearing curve parameters, as well as low roughness, were obtained for the amplitude $A=14 \mathrm{~mm}$. The application of low amplitude values, the consequence of which is lower impact energy, causes incomplete levelling of micro- irregularities after machining preceding shot peening, a too high value of the amplitude, in turn, causes deformation of the machied surface.

Having performed the studies one can notice that for all sets of shot peening parameters the

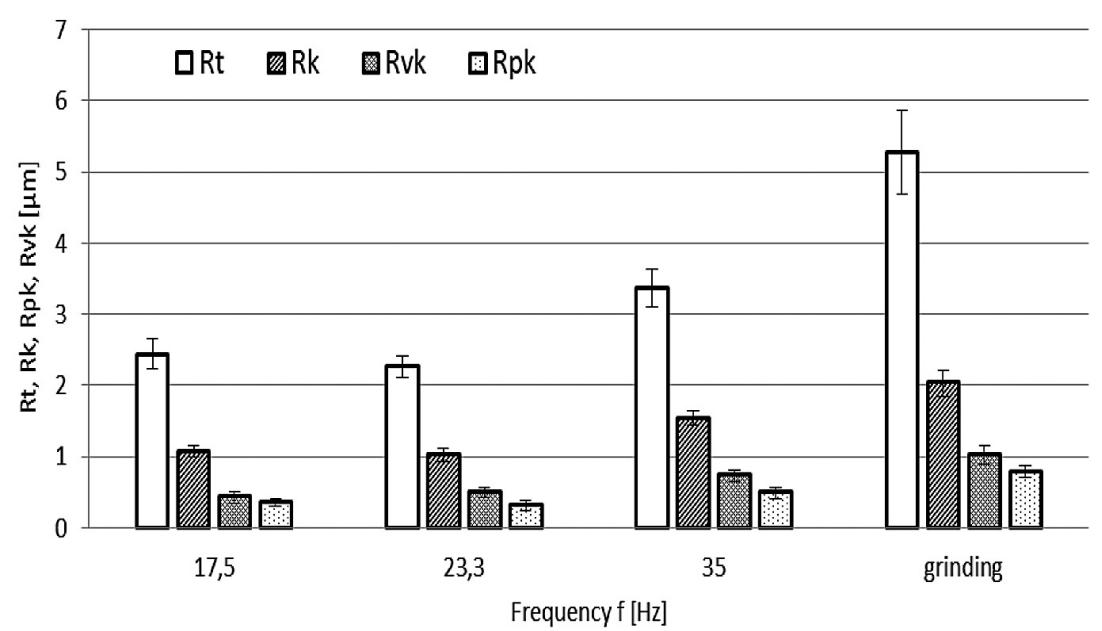

Fig. 6. Effect of vibrator vibrations frequency onto surface roughness parameter and bearing curve parameters 


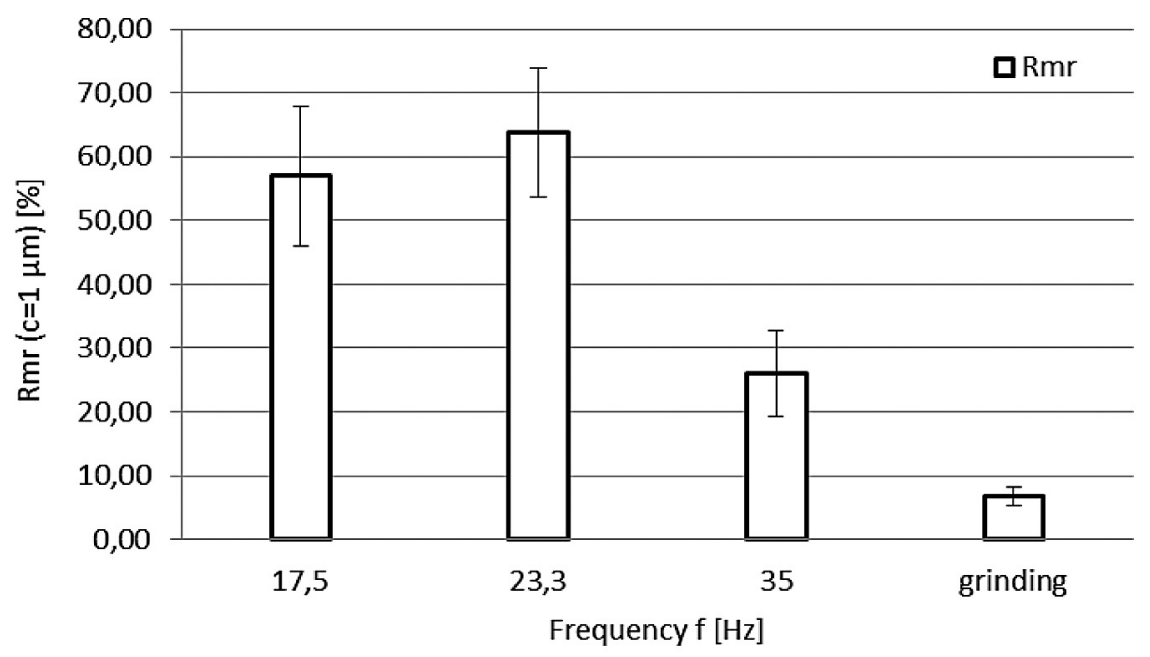

Fig. 7. Effect of vibrator vibrations frequency onto material ratio at depth $c$ Rmr

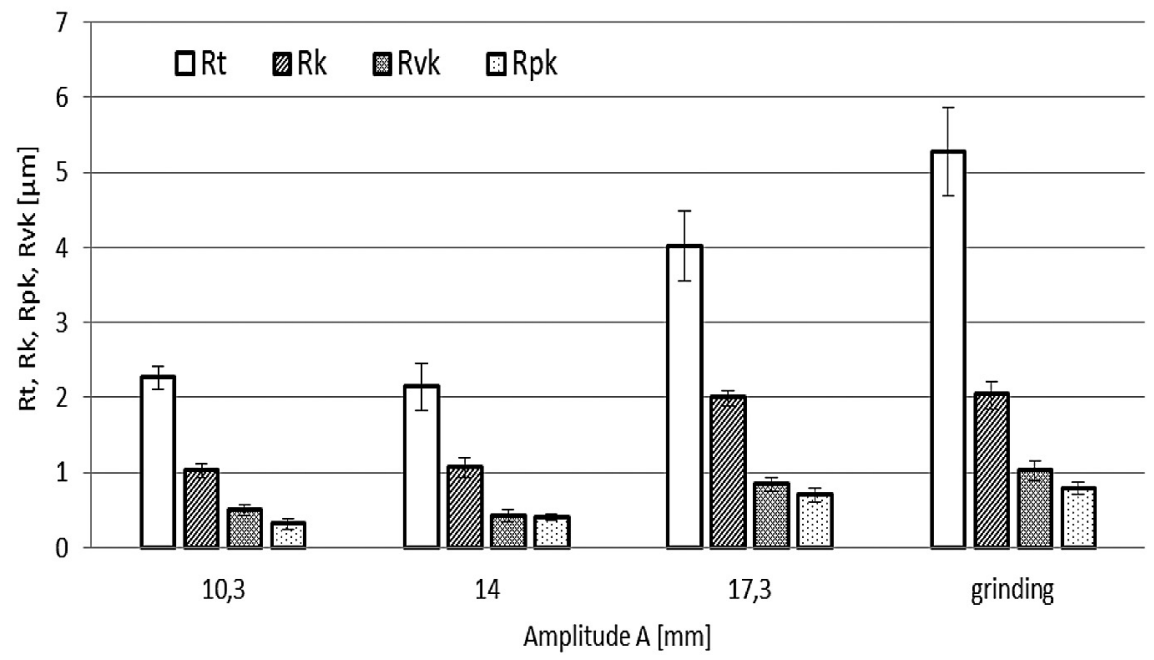

Fig. 8. Effect of vibrator vibrations amplitude onto surface roughness parameter and bearing curve parameters

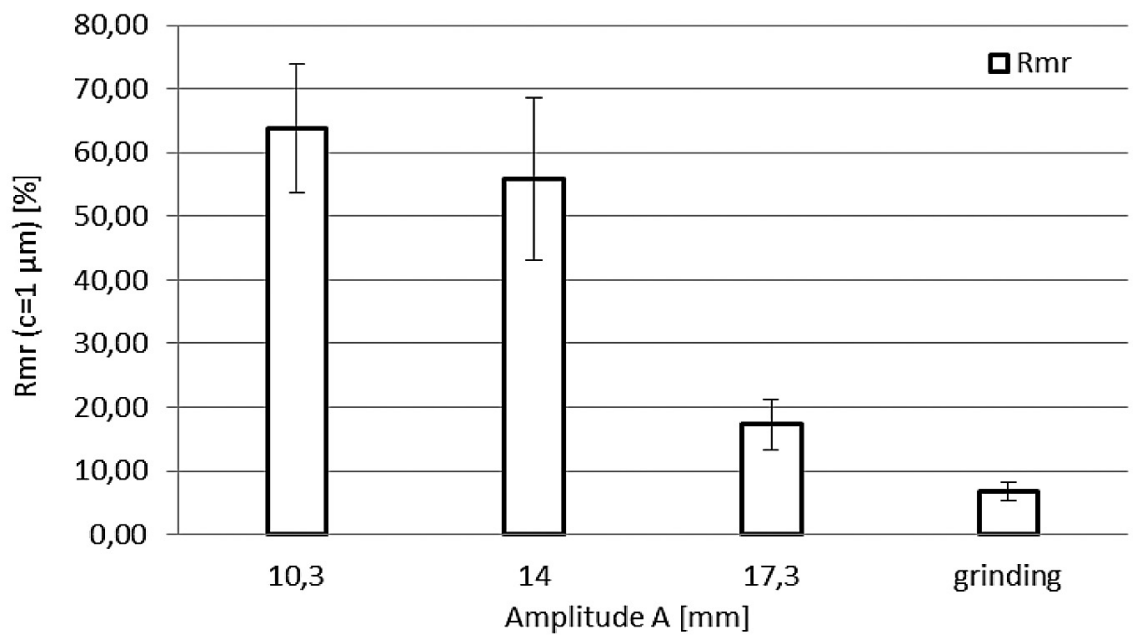

Fig. 9. Effect of vibrator vibrations amplitude onto material ratio at depth $c$ Rmr 
a)

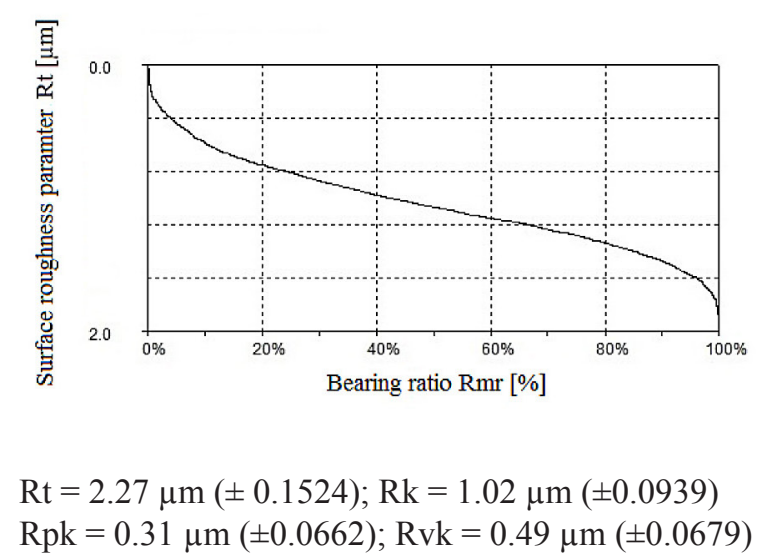

b)

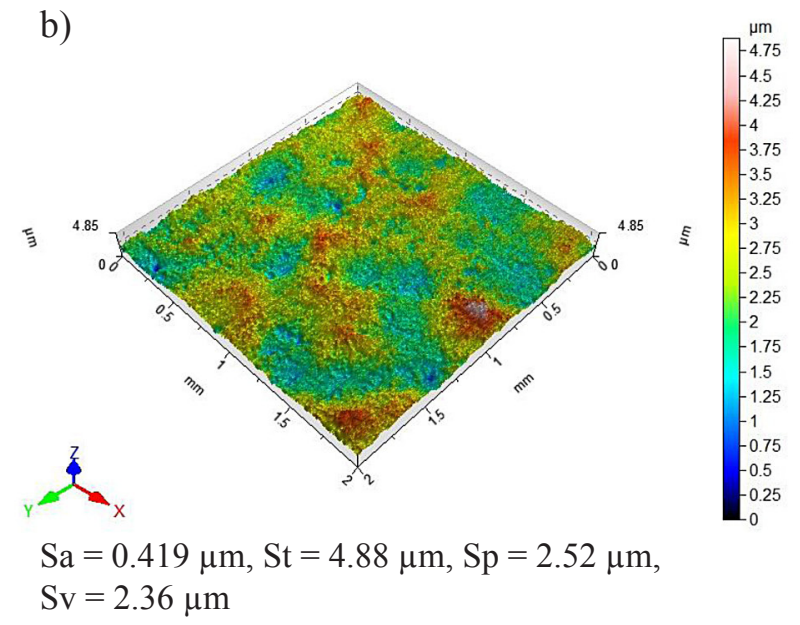

Fig. 10. Bearing curve, surface topography and surface roughness parameters $2 \mathrm{D}$ and $3 \mathrm{D}$ after vibratory shot peening (machining parameters $d=9.4 \mathrm{~mm}, t=5 \mathrm{~min}, v=23.3 \mathrm{~Hz}, A=14 \mathrm{~mm}$ )

obtained values of roughness and bearing curve were lower with reference to surface after grinding. The Rpk parameter, maintained during surface lapping, after shot peening achieved from $11 \%$ to $61 \%$ smaller values than after grinding. This proves high abrasion resistance of surfaces machined by vibration shot peening. In the case of Rvk parameter smaller values were achieved: from $17 \%$ to $58 \%$ in relation to the ground surface. That may mean that the surfaces treated in this way have smaller oil maintenance capacity.

The geometrical structure of the surface after vibration shot peening (Figure 10) is disordered. The total roughness profile is visibly decreased, and there are characteristic hollows, formed in result of the balls striking against the sample surfaces. The bearing curve of roughness profile is of degressive-progressive nature. It has flattened vertexes of micro-irregularities, which probably means increased abrasion resistance of the treated surface.

\section{CONCLUSIONS}

In this paper we examined the effect of technological parameters of vibration shot peening upon the shape of bearing curve, as well as the parameters related to Abbott-Firestone curve. The following results sum up the conducted studies.

In the effect of vibration shot peening the $R p k$ parameter decreased from $11 \%$ to $61 \%$ with reference to values after grinding. That proves the increase of abrasion resistance. For $R v k$ parameter the change ranged from $17 \%$ to $58 \%$, which meant that the surfaces machined in this way have lower oil maintenance capacity. The material ratio at depth $c$ of surface roughness profile is from 2.5 to 9.5 times greater after vibration shot peening than after grinding. This allows for increasing the surface mating time in frictional pair.

The profile bearing curve after shot peening assumes degressive-progressive character and has a small angle of inclination. Technological parameters of vibration shot peening affect the parameters of bearing curve.

\section{REFERENCES}

1. Adamczak S., Normalizacja pomiarów struktury geometrycznej powierzchni. Cz. 8. Mechanik, 8-9, 2005, 690-692.

2. Corral I.B., Calvet J.V., Salcedo M.C., Use of roughness probability parameters to quantify the material removed in plateau-honing. International Journal of Machine Tools \& Manufacture, 50, 2010, 621-629.

3. Czarnecki H., Analiza teoretyczna wpływu stereometrii powierzchni na działanie pary tribologicznej. Tribologia, 4, 2005, 19-31.

4. Deepak L.K., Rammamoorthy B., Surface topography characterization of Automotive cylinder liner surfaces using fractal methods. Applied Surface Science, 280, 2013, 332-342.

5. Gałda L., Możliwości kształtowania regularnej geometrii czopów łożysk ślizgowych w procesie obróbki nagniataniem udarowym. Tribologia, 3, 2004, 111-119.

6. Koszela W., Gałda L., Dzierwa A., Pawlus P., Sęp J., Wpływ kieszeni smarowych na zatarcie pary ciernej stal-brąz. Tribologia, 3, 2009, 51-58.

7. Laber S., Wpływ stanu warstwy wierzchniej na właściwości tribologiczne żeliwa sferoidalnego 
ferrytycznego po nagniataniu. Tribologia, 1, 2010, 51-59.

8. Niżankowski C., Matras A., Wpływ gatunku ścierniwa na dokładność wałków stalowych po szlifowaniu ściernicowym. Inżynieria Maszyn, 15 (3), 2010, 55-68.

9. Petropoulos G.P., Torrance A.A., Pandazaras C.N., Abbott curves characteristics of turned surfaces. International Journal of Machine Tools \& Manufacture, 43, 2003, 237-243.

10. Sahlin F., Almqvist A., Larrson R., Glavatskih S., Rough surface flow factors in full film lubrication based on a homogenization technique. Tribology International, 40, 2007, 1025-1034.

11. Wieczorowski M., Cellary A., Chajda J., Przewodnik po pomiarach nierówności powierzchni czyli o chropowatości i nie tylko. Zakład PoligraficznoWydawniczy M-Druk, Poznań 2003.
12. Zaleski K., Kształtowanie wybranych właściwości warstwy wierzchniej elementów metalowych w procesie dynamicznego nagniatania rozproszonego. Wydawnictwo Politechniki Lubelskiej, Lublin 2008.

13. Zaleski K., Modelowanie chropowatości powierzchni i stopnia umocnienia warstwy wierzchniej stali 30HGSA po nagniataniu wibracyjnym. Mechanik, 3, 2007, 194-198.

14. Żebrowski H., Kowalski M., Pomiary chropowatości i stereometryczny opis struktury powierzchni gładzonych. Prace Naukowe Instytutu Technologii Maszyn i Automatyzacji Politechniki Wrocławskiej, 74, 1999, 227-234.

15. PN-EN ISO 13565-2. Struktura geometryczna powierzchni: metoda profilowa; powierzchnie o warstwowych właściwościach funkcjonalnych.

16. PN-EN ISO 4287. Struktura geometryczna powierzchni: metoda profilowa. 